\title{
FLEKSIBILITAS PEMBELAJARAN DARING PADA MASA PANDEMI COVID-19
}

\section{FLEXIBILITY OF ONLINE LEARNING DURING COVID-19 PANDEMIC}

\author{
Muhammad Rifa'ie \\ Universitas Mandala Waluya \\ Jalan Jend. A.H. Nasution No. G37 Kambu, Kota Kendari, Sulawesi Tenggara \\ E-mail: mrifaie552@gmail.com
}

Naskah diterima tanggal: 16-05-2020, disetujui tanggal: 21-10-2020

\begin{abstract}
Covid-19 pandemic has caused serious problems to learning activities in schools especially for face-to-face learning. As a consequence, mastery in the flexibility of online learning is a skill that teachers must possess. The purpose of the research was to elaborate the flexibility of learning content and online classroom organization during the pandemic of Covid-19 pandemic. This research used a qualitative approach. The subject of research was 35 students from class $X$ in Visual communication design study program at SMK Negeri 5 Yogyakarta. Data collection in this study used triangulation techniques. The results showed that the flexibility of content during online learning is set on by providing new and innovative learning content by using a combination of media and delivery modes that include interactive videos, comics, selfies, animations, scientific posters, instagram, twitter, facebook, tiktok, and youtube. It was also revealed that the organizing online classes is arranged in a flexible manner using the support capacity of communication technology and Learning Management System to optimize the use of learning strategies through the media platform of google classroom, google form, and hangouts meet. In brief, the flexibility of online learning is determined by the success of teacher in choosing independent learning strategies that provides students the opportunity to have the freedom to determine their own learning methods and use learning media effectively.
\end{abstract}

Keywords: flexible learning, online learning, covid-19, biography text

\begin{abstract}
Abstrak: Pandemi Covid-19 memunculkan persoalan yang serius terhadap kegiatan pembelajaran secara tatap muka di sekolah. Oleh sebab itu, fleksibilitas pembelajaran dalam jaringan (daring) merupakan keterampilan yang harus dikuasai oleh guru. Penelitian ini bertujuan untuk menjelaskan fleksibilitas konten pembelajaran dan fleksibilitas pengorganisasian kelas daring selama masa pandemi Covid-19. Penelitian ini menggunakan pendekatan kualitatif. Subjek penelitian ialah 35 peserta didik kelas $X$ jurusan Desain Komunikasi Visual di SMK Negeri 5 Yogyakarta. Pengumpulan data dalam penelitian ini menggunakan teknik triangulasi. Hasil penelitian menunjukkan bahwa fleksibilitas konten selama pembelajaran daring ditentukan dari penyediaan konten pembelajaran dengan cara baru dan inovatif dengan menggunakan kombinasi media dan mode pengiriman yang mencakup video interaktif, komik, swafoto, animasi, poster ilmiah, instagram, twitter, facebook, tiktok, dan youtube. Hasil penelitian juga mengungkap bahwa pengorganisasian kelas daring diatur secara fleksibel menggunakan daya dukung teknologi komunikasi dan Learning Management System (LMS) untuk mengoptimalkan penggunaan strategi pembelajaran melalui media platform google classroom, google formulir, dan hangouts meet. Dengan demikian, fleksibilitas pembelajaran daring ditentukan oleh keberhasilan guru dalam memilih strategi pembelajaran yang mandiri sehingga peserta didik mampu memiliki
\end{abstract}


kebebasan untuk menentukan cara pembelajarannya sendiri dan menggunakan media pembelajaran yang efektif.

Kata kunci: pembelajaran fleksibel, pembelajaran daring, Covid-19, teks biografi

\section{PENDAHULUAN}

Novel Coronavirus Disease (Covid-19) secara resmi pertama kali diumumkan oleh Pusat Pengendalian dan Pencegahan Penyakit Tiongkok sebagai penyakit yang menular pada tanggal 8 Januari 2020 (Li, Guan, Wu, Xiaoye, Zhou, Tong, et al., 2020; Meng, Hua, \& Bian, 2020). Pada awalnya, Covid-19 diidentifikasi sebagai 2019-nCoV. Gejala penyakit ini ditandai dengan sindrom pernafasan akut yang menyerang paru-paru manusia.

Covid-19 mulanya muncul di kota Wuhan, Tiongkok. Namun, penyakit ini dengan cepat menyebar ke berbagai negara di dunia (Phelan, Katz, \& Gostin, 2020). Akibatnya, Covid-19 pun menjadi permasalahan internasional yang melingkupi berbagai batas-batas suku, bangsa, dan negara (Mahase, 2020). Organisasi Kesehatan Dunia pada tanggal 26 Februari 2020 secara resmi mengumumkan bahwa Covid-19 adalah penyakit pandemik yang telah menyebar ke 34 negara dengan total kasus positif 80.239 dan korban jiwa 2.700 (World Health Organization, 2020).

Penyebaran Covid-19 tidak hanya berdampak buruk terhadap kesehatan manusia, tetapi juga berdampak buruk terhadap sektor pendidikan, baik dalam ruang lingkup internasional maupun dalam ruang lingkup nasional. Organisasi Pendidikan, Keilmuan, dan Kebudayaan Perserikatan Bangsa-Bangsa (UNESCO) melaporkan bahwa terdapat 46 negara di lima benua telah menutup sekolah untuk menghentikan penyebaran Covid-19; 26 negara menutup sekolah yang berdampak besar terhadap proses pembelajaran terhadap sekitar 376,9 juta siswa; dan 20 negara lainnya menutup sebagian sekolah untuk mencegah penyebaran Covid-19 (Huang, Liu, Tlili, Yang, \&
Wang, 2020).

Indonesia termasuk salah satu negara yang terdampak. Kementerian Kesehatan Republik Indonesia (2020) pada tanggal 4 Februari 2020 menetapkan Novel Coronavirus Disease sebagai penyakit yang dapat menimbulkan wabah. Jumlah total positif Covid-19 sebanyak 9.096 orang, korban jiwa 765, sembuh 1.151, Orang dalam Pemantauan (ODP) 210.199, dan Pasien dalam Pengawasan (PDP) sebanyak 19.987 (Kementerian Kesehatan Republik Indonesia, 2020). Data tersebut masih belum stabil dan kemungkinan ada kenaikan atau justru sebaliknya. Keadaan darurat ini pun ditetapkan melalui Peraturan Pemerintah Republik Indonesia Nomor 21 Tahun 2020 tentang Pembatasan Sosial Berskala Besar (PSBB) untuk percepatan penanganan Covid-19 dengan peliburan sekolah dan tempat kerja, pembatasan kegiatan keagamaan, dan pembatasan kegiatan di fasilitas umum. Berkaitan dengan pendidikan, Kementerian Pendidikan dan Kebudayaan Republik Indonesia (2020) pada tanggal 24 Maret 2020 mengeluarkan surat edaran tentang pelaksanaan kebijakan pendidikan dalam masa darurat penyebaran coronavirus disease dengan salah satu kebijakan pokok tentang pembelajaran jarak jauh.

Pembelajaran jarak jauh merupakan proses pembelajaran yang dilakukan secara jarak jauh melalui penggunaan berbagai media. Pembelajaran jarak jauh ini ditandai dengan perbedaan ruang antara peserta didik dan guru. Pembelajaran ini memanfaatkan berbagai variasi media dan teknologi untuk menyampaikan materi kepada peserta didik, sehingga memungkinkan memperkecil batas ruang antara guru dan peserta didik (Bušelić,2012; Susanti, Halimah, Harta, \& Karyana, 2018). 
Kebijakan pembelajaran jarak jauh ini dapat memengaruhi model pembelajaran yang selama ini dilakukan di sekolah. Pembelajaran yang dilakukan di rumah tetap menuntut guru untuk mencapai Kompetensi Dasar (KD) yang masih berjalan pada masa pandemi. Implementasi Kurikulum 2013 memerlukan berbagai inovasi terutama pemanfaatan Teknologi Infomasi dan Komunikasi (Anwas, 2014). Walaupun demikian, pilihan pembelajaran yang digunakan oleh sekolah adalah pembelajaran dalam jaringan (daring/online).

Pembelajaran daring merupakan model pembelajaran yang berbasis ICT (Information Communication Technology). Daya dukung program ini ialah fasilitas berupa web, LMS (Learning Management System), program monitoring, modular, dan multimedia (Dewi, 2017).

Materi teks biografi termasuk ke dalam mata pelajaran Bahasa Indonesia KD 3.14, KD 3.15, KD 4.14, dan KD 4.14 di tingkat SMA/MA/SMK/ MAK kelas $X$ dalam Kurikulum 2013 revisi selama masa awal pandemi. Untuk mencapai Standar Nasional Pendidikan, pendidik wajib merencanakan pembelajaran dalam bentuk Silabus dan Rencana Pelaksanaan Pembelajaran (RPP) yang mengacu pada Standar Isi. Dalam tugas tersebut, guru diminta untuk membuat Indikator Pencapaian Kompetensi (IPK) pada saat menyusun silabus mata pelajaran yang telah diuraikan dalam Permendiknas Nomor 16 Tahun 2007 (Indaryanti, Susanti, Aisyah, \& Scristia, 2019). Analisis dan pelaksanaan terhadap Kompetensi Dasar (KD) pembelajaran menjadi sangat penting untuk dilakukan. Namun, hal ini memunculkan persoalan jika dihadapkan dengan pandemi covid-19.

Pembelajaran tidak lagi bisa menyesuaikan dengan RPP karena pembelajaran dilakukan secara daring. Dengan demikian, proses pembelajaran daring yang direkomendasikan oleh UNESCO seharusnya menggunakan pendekatan pembelajaran fleksibel (flexible learning).
Sejalan dengan pembelajaran daring, pendekatan pembelajaran yang fleksibel pun dirancang dengan menggunakan berbagai metode. Hal ini bertujuan untuk memberikan kesempatan kepada peserta didik agar dapat mengakses informasi yang melingkupi hubungan antara peserta didik dengan guru. Akses informasi dapat terjadi dengan menggunakan alat berbasis internet seperti $L M S$ melalui konten yang tersedia secara elektronik dan berjarak jauh, serta dengan penggunaan strategi "tatap muka" secara virtual (Joan, 2013).

Pembelajaran fleksibel memberikan kesempatan kepada peserta didik untuk memilih proses pembelajaran sesuai dengan kebutuhan pribadinya. Pilihan pembelajaran ini dapat mencakup materi, pendekatan, sumber daya, lokasi pembelajaran, waktu pembelajaran, penggunaan teknologi, dan media komunikasi (Collis, Vingerhoets, \& Moonen, 1997; Goode, Willis, Wolf, \& Harris, 2007). Sementara pembelajaran konvensional mengharuskan peserta didik untuk mengikuti urutan karena terikat oleh waktu, konten, dan tempat. Dengan demikian, pembelajaran daring dapat disebut sebagai pembelajaran yang fleksibel karena peserta didik dapat mengontrol proses pembelajaran, kecepatan, dan kontinguitasnya (Hannafin, 1984). Selain itu, Steinberg (1989) mengemukakan bahwa semakin banyak peserta didik yang dapat mengendalikan lingkungan belajarnya, semakin besar motivasi belajarnya. Pada akhirnya, motivasi peserta didik tersebut membuka peluang untuk membuat mereka menjadi lebih mandiri, sedangkan guru dapat mengoptimalkan perannya sebagai fasilitator pembelajaran.

Dalam pembelajaran fleksibel, peran teknologi dan komunikasi dianggap sebagai komponen penting yang dapat menyediakan pembelajaran daring secara dua arah. Ryan \& Tilbury (2013) percaya bahwa fleksibilitas bukan hanya atribut, tetapi juga strategi pendidikan di tingkat institusi. 
Huang, et al., (2020) menyimpulkan bahwa pembelajaran fleksibel memiliki beberapa karakteristik. Pertama, pembelajaran fleksibel menawarkan pilihan belajar yang bervariasi bagi peserta didik. Kedua, pembelajaran fleksibel menerapkan pendekatan konstruktivisme yang berpusat pada peserta didik. Ketiga, peserta didik diberikan berbagai pilihan pembelajaran sehingga dapat lebih bertanggung jawab.

Pembelajaran fleksibel sudah diterapkan di Australia bagian selatan pada tahun 2006 sebagai model pembelajaran alternatif yang dikhususkan bagi perserta didik yang mengalami permasalahan kompleks. Peserta didik dalam pembelajaran ini biasanya peserta didik yang kehilangan haknya dalam pembelajaran konvensional di sekolah. Melalui program pembelajaran fleksibel tersebut, pemerintah Australia berupaya untuk meningkatkan kualitas remaja dan anak-anak yang lebih awal keluar dari sekolah. Asumsinya, program pembelajaran fleksibel diyakini bisa menjadi alternatif dan sekaligus memberikan kesempatan kedua bagi anak-anak dan para remaja (te Riele, 2006; te Riele, 2012; Smyth \& McInerney, 2013). Namun, menurut hasil penelitian te Riele (2006) pogram pembelajaran fleksibel memiliki keberhasilan yang terbatas dan bahkan memungkinkan dapat meminggirkan yang terpinggirkan (marginalise the marginalised).

Alasan utama kurangnya keberhasilan tampaknya dipicu oleh kurangnya komitmen pendanaan publik dan swasta. Selain itu, pada umumnya terdapat kekurangan sumber daya guru yang berpengalaman. Program pembelajaran fleksibel pada awalnya berkembang dengan baik tetapi kemudian dengan cepat mengalami penurunan (Giles \& Hargreaves, 2006).

Pemerintah Tiongkok pun pernah menerapkan pembelajaran fleksibel pada tahun 2020 ketika Covid-19 dinyatakan sebagai wabah nasional dengan tujuan untuk mencegah laju penyebaran wabah. Berdasarkan catatan
Huang, et al., (2020) Kementerian Pendidikan Tiongkok mengoordinasikan 22 platform pembelajaran daring yang secara total menawarkan 24.000 kursus daring gratis dan terbuka di tingkat nasional. Sekolah dan perusahaan pendidikan di tingkat provinsi juga menyediakan sejumlah besar sumber pembelajaran terbuka sehingga kuantitas dan fleksibilitas sumber daya dapat dijamin selama periode khusus wabah Covid-19.

Berdasarkan penelitian Huang, et al., (2020) pemerintah Tiongkok berhasil menerapkan pembelajaran fleksibel dengan pengelolaan elemen-elemen inti, yaitu: a) infrastruktur, b) alat belajar, c) sumber belajar, d) metode pembelajaran, e) layanan untuk guru dan siswa, serta f) kerja sama antara pemerintah, perusahaan, dan sekolah.

Saat ini, Indonesia menerapkan pembelajaran jarak jauh (PJJ) dengan tujuan untuk mencegah penyebaran Covid-19 secara meluas. Purwanto, Pramono, Asbari, Santoso, Wijayanti, Hyun, \& Putri, (2020) meneliti dampak Covid19 terhadap pembelajaran sekolah dasar di Banten. Hasil dari penelitian tersebut mengungkapkan kurang penguasaan terhadap teknologi, penambahan biaya kuota internet, adanya pekerjaan tambahan bagi orang tua untuk mendampingi anak belajar, komunikasi dan sosialisasi antarsiswa, guru, dan orang tua menjadi berkurang, sementara jam kerja menjadi tidak terbatas bagi guru karena harus selalu berkomunikasi dan berkoordinasi dengan orang tua, guru lain, dan kepala sekolah.

Penelitian-penelitian yang dilakukan sebelumnya belum secara spesifik meneliti fleksibilitas pembelajaran daring teks biografi di Sekolah Menengah Kejuruan (SMK). Padahal, penilitian ini penting untuk mengungkapkan proses fleksibilitas pembelajaran daring pada saat pandemi Covid-19. Dengan demikian, guru, sekolah, pemerintah, dan masyarakat memiliki pilihan untuk menerapkan pembelajaran yang fleksibel sehingga proses pembelajaran tetap 
akan berjalan secara efektif dan menyenangkan.

Berdasarkan latar belakang tersebut, rumusan masalah dalam penelitian ini ialah: 1 ) bagaimana fleksibilitas konten pembelajaran teks biografi selama masa pandemi Covid-19? 2) bagaimana fleksibilitas pengorganisasian kelas selama pembelajaran daring pada masa pandemi Covid-19?

Berdasarkan rumusan masalah tersebut, tujuan penelitian ini ialah mengelaborasi: 1) fleksibilitas konten pembelajaran teks biografi selama masa pandemi Covid-19; dan 2) fleksibilitas pengorganisasian kelas selama pembelajaran daring pada masa pandemi Covid19.

Manfaat dari penelitian ini antara lain dapat membantu para pendidik, peneliti, dan praktisi untuk melaksanakan sekaligus memberikan solusi terhadap studi kasus fleksibilitas pembelajaran daring selama masa pandemi Covid-19. Sebagaimana ditekankan oleh Stefania Giannini, Asisten Direktur Jenderal Pendidikan UNESCO: "Kita perlu bersatu tidak hanya untuk mengatasi konsekuensi langsung pendidikan dari krisis yang belum pernah terjadi sebelumnya ini, tetapi juga untuk membangun ketahanan jangka panjang dari sistem pendidikan" (Huang, et al., 2020).

\section{METODE}

Penelitian dilaksanakan pada semester genap tahun ajaran 2019/2020 di SMK Negeri 5 Yogyakarta dengan menggunakan pendekatan kualitatif. Subjek penelitian ialah 35 siswa kelas $X$ jurusan Desain Komunikasi Visual yang menempuh mata pelajaran Bahasa Indonesia dengan materi teks biografi.

Pengumpulan data dalam penelitian ini menggunakan teknik triangulasi yang mencakup dokumentasi, observasi, dan kuesioner (terbuka dan tertutup). Teknik dokumentasi digunakan untuk mengumpulkan data dari guru dan siswa yang bersumber dari LMS google classroom, aplikasi whatsApp, google formulir, dan catatan pembelajaran dari guru Bahasa Indonesia mulai dari perencanaan, proses pembelajaran sampai pada asesmen pembelajaran teks biografi selama masa pandemi. Observasi digunakan untuk mengumpulkan data mengenai fleksibilitas konten dan pengorganisasian kelas pembelajaran daring, sedangkan teknik kuesioner menggunakan lembar kuesioner melalui google formulir yang disebarkan kepada peserta didik. Lembar kuesioner dirancang berbasis pada dua dimensi fleksibilitas pembelajaran daring, yaitu: fleksibilitas konten dan fleksibilitas pengorganisasian kelas.

Langkah-langkah yang dilakukan adalah kondensasi data (memilih, menyederhanakan, mengabstraksi, mengubah data yang mendekati keseluruhan bagian dari catatan lapangan tertulis, dokumentasi, dan bahan empiris lainnya), tampilan data (pengorganisasian, penggabungan informasi untuk kemungkinan kesimpulan dan tindakan), dan kesimpulan (menarik kesimpulan dan memverifikasi) (Miles, Huberman, \& Saldana, 2014).

\section{HASIL DAN PEMBAHASAN}

Pada awal periode pandemi Covid-19, guru mata pelajaran Bahasa Indonesia di SMK Negeri 5 Yogyakarta mendorong peserta didik untuk mengampanyekan aksi melawan Covid-19. Tujuan kampanye ini adalah untuk mengedukasi peserta didik terhadap dampak negatif Covid19 dengan enam variasi topik seperti mencuci tangan, berdiam diri di dalam rumah, pembatasan sosial, pembatasan fisik, tidak berjabat tangan, memakai masker, dan menjaga kesehatan tubuh. Topik-topik tersebut dikembangkan oleh peserta didik dalam bentuk komik, swafoto, animasi, video, dan poster.

Gambar komik dimaknai sebagai parodi sekaligus kritik terhadap perilaku masyarakat yang tidak menerapkan pembatasan sosial, sementara gambar swafoto dan poster berisi anjuran kepada masyarakat untuk memakai masker dan sekaligus menjauhi ruang publik. Kampanye pencegahan ini disebarluaskan melalui 
media sosial seperti instagram, twitter, facebook, tiktok, dan youtube. Konten di dalam masing-masing komik, poster, swafoto, animasi, dan video tersebut dibuat secara fleksibel menyesuaikan berdasarkan minat dan kepribadian peserta didik. Dengan demikian, melalui kegiatan kampanya tersebut, peserta didik memegang kendali terhadap konsep pembelajarannya sendiri secara mandiri.
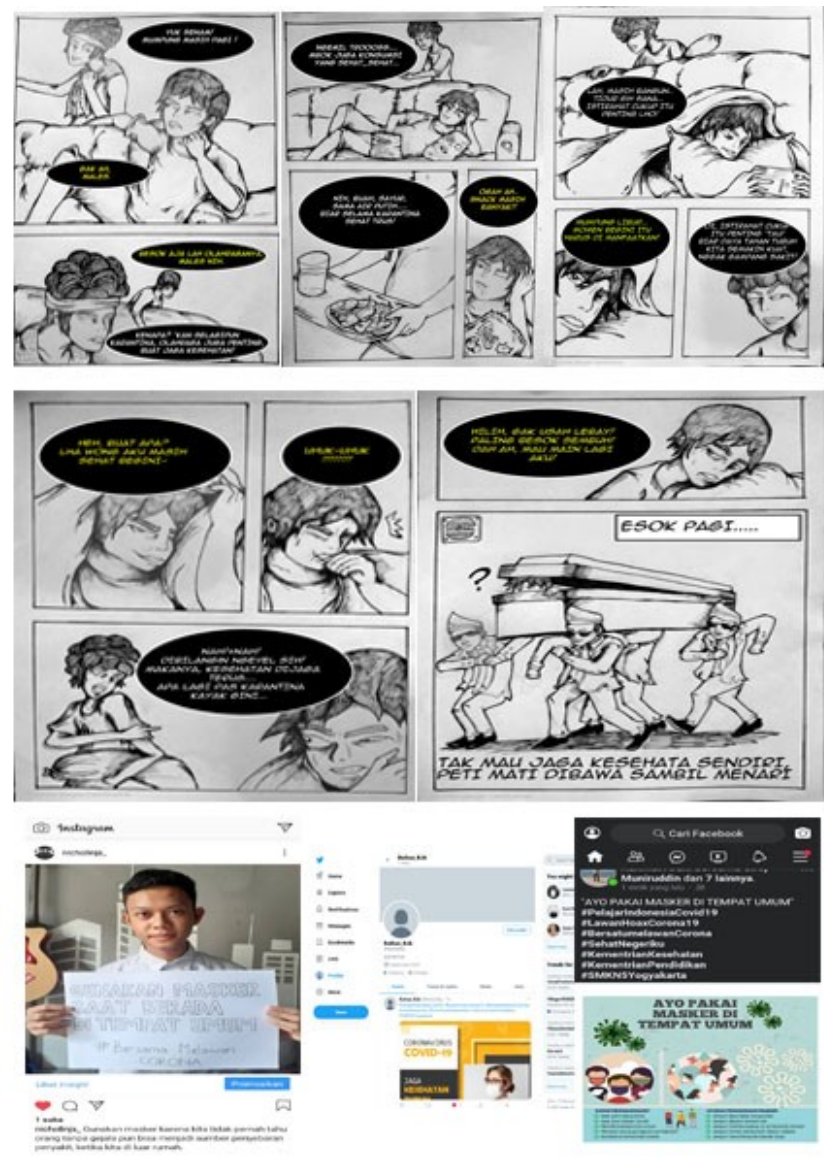

Gambar 1 Peserta Didik Sedang Melakukan Kampanye Pencegahan Covid-19

Dalam kegiatan ini, peserta didik telah menjadi subjek pembelajaran dengan konstruksi produk yang mereka rancang sendiri sesuai kemauan dan motivasi mereka untuk mengedukasi dirinya sendiri dan sekaligus mengedukasi masyarakat luas melalui media pengiriman yang berbeda-beda. Adapun media mengiriman tersebut menawarkan berbagai pilihan cara sehingga peserta didik dapat mengakses materi pembelajaran dari berbagai sumber (Collis, et al., 1997). Hal ini memungkinkan peserta didik untuk menggabungkan antara kegiatan kampanye dengan kegiatan studi untuk menghasilkan peluang belajar inovatif dari berbagai sudut pandang yang luas. Pilihan belajar itu pun didukung oleh peran guru sebagai fasilitator pembelajaran dengan pengembangan strategi pembelajaran yang efektif, seperti pembelajaran dengan tutorial, penugasan, diskusi, kelompok seminar, debat, pendekatan inkuiri yang dipimpin siswa, dan/ atau permainan (Gordon, 2014). Strategistrategi tersebut diasumsikan menawarkan lebih banyak kesempatan bagi peserta didik untuk mengendalikan proses belajar mereka sendiri dan meningkatkan pengalaman belajar secara mandiri.

Dalam hal ini, guru mata pelajaran bahasa Indonesia kelas $X$ di SMK Negeri 5 Yogyakarta menggunakan strategi penugasan sebagai suatu bentuk pembelajaran mandiri melalui perangkat lunak google classroom. Tugas tersebut selanjutnya dibahas dalam pembelajaran video konferensi daring di hangouts meet sehingga siswa dapat memiliki persepsi emosional yang lebih baik ketika mereka sedang melakukan proses pembelajaran melalui video konferensi. Dengan demikian, pembelajaran dapat berlangsung secara dua arah.

Tugas pertama ialah meneladani sosok tokoh Bacharuddin Jusuf Habibie melalui film biografi Rudy Habibie yang disutradarai oleh Hanung Bramanyo pada tahun 2016. Film ini menceritakan kehidupan Habibie dari masa kecil sampai remaja dimana Habibie muda ingin mewujudkan cita-cita ayahnya untuk membuat pesawat terbang. Akhirnya, Habibie kuliah di Jerman dan kemudian berhasil mewujudkan rancangan Industri Dirgantara Indonesia sebagai strategi menjawab tantangan Indonesia di masa depan. Melalui film itu, peserta didik diminta menyatakan pendapatnya tentang karakter unggul tokoh film dengan tujuan untuk meneladani sosok Bacharuddin Jusuf Habibie. 
Penggunaan film biografi Rudy Habibie sebagai media pembelajaran sangat penting bagi peserta didik, terlebih lagi film tersebut dapat berperan sebagai pelengkap konten pembelajaran dari teks biografi yang ada dalam buku teks pelajaran. Terlepas dari seberapa baik peristiwa sejarah suatu zaman diajarkan secara kronologis atau logis, peserta didik tidak dapat menganggap peristiwa ini sebagai realistis dan konkret seperti kehidupan seseorang. Dalam konteks ini, film biografi Rudy Habibie memberi kesempatan peserta didik untuk mendapatkan pandangan sekilas dan pemahaman yang lebih baik dari sudut pandang seseorang yang hidup pada periode itu. Kisah hidup orang-orang hebat, pemimpin, dan pahlawan memberi kita wawasan tentang era atau tren tertentu, sementara kisah-kisah itu menjelaskan peristiwa-peristiwa abstrak dan tak terpecahkan yang terjadi pada periode itu (Er, 2005).

Dengan menggunakan film biografi, peserta didik dapat memahami bagaimana individu dan masyarakat mengubah arah sejarah, merasakan urutan, variabilitas, dan kegigihan peristiwa sejarah membangun hubungan yang bermakna dan koneksi di antara mereka (Fertig, 2005). Hubungan emosional antara peserta didik dengan tokoh dalam film memungkinkan peserta didik menarik hubungan yang samar antara peserta didik sebagai subjek dengan tokoh film sebagai sumber inspirasi. Mereka memberi jarak yang sangat presisi sehingga dapat menarik beragam pengalaman abstrak yang diredefinisikannya sebagai karakter unggul. Karakter unggul tersebut seperti, berani mengambil resiko, demokratis (bermusyawarah untuk kepentingan masyarakat), fokus pada tujuan dan visi misi, memiliki jiwa pemimpin, memiliki sifat yang tegas, memiliki mimpi yang besar, mencintai tanah air, pantang menyerah, pekerja keras, pluralis (menghargai perbedaan suku), taat dalam beribadah, dan teguh pada pendirian (lihat Tabel 1).
Dengan demikian, karakter-karakter unggul tersebut dapat memenuhi kebutuhan emosional peserta didik untuk membimbing sebagaimana yang diyakini dapat membangun masa depan mereka (Kaymakcý \& Er, 2009). Penanaman pendidikan karakter terhadap anak didik perlu dilakukan melalui media massa yang dapat mendorong dan menciptakan masyarakat pembelajar, menjadi inspirasi, mencerdaskan, serta memberikan contoh keteladanan (Anwas, 2011).

Tabel 1 Peserta Didik Meneladani Karakter Unggul Tokoh Rudy Habibie

\begin{tabular}{ll}
\hline No. & Karakter Unggul \\
\hline 1 & Berani mengambil resiko \\
2 & Demokratis \\
3 & Fokus pada tujuan dan visi-misi \\
4 & Memiliki sifat yang tegas \\
5 & Memiliki mimpi yang besar \\
6 & Mencintai tanah air \\
7 & Pantang menyerah \\
8 & Pekerja keras \\
9 & Pluralisme \\
10 & Taat beribadah \\
11 & Teguh pada pendirian \\
\hline
\end{tabular}

Penugasan selanjutnya ialah guru meminta peserta didik untuk menentukan sendiri tokoh biografi yang mereka teladani, setelah itu peserta didik diminta untuk menceritakan kembali biografi tokoh tersebut. Kemudian pada akhir kegiatan, peserta didik diminta menghubungkan secara didaktik antara karakter unggul tokoh biografi dengan cita-cita yang ingin diraih oleh peserta didik di masa depan.

Hasil dari kegiatan pembelajaran ini sangat menarik, sejumlah besar peserta didik memiliki pengalaman yang berbeda-beda dengan pilihan sosok tokoh biografinya. Setelah dilakukan kategorisasi, tokoh-tokoh pilihan peserta didik tersebut terbagi menjadi tokoh religius, 
nasionalis, pengusaha, seniman, motivator, olahragawan, dan kaum milenial.

Tokoh religius muncul nama Agnes Gonxa Bojaxhiu (Ibunda Taresa) dan Nabi Daud. Dari tokoh nasionalis muncul nama Mahatma Ghandi, Ir. Sukarno, Raden Suwardi Suryaningrat, Jendral Sudirman, Raden Ajeng Kartini, dan Presiden Joko Widodo. Dari tokoh pengusaha muncul nama Thomas Alva Edison, Jack Ma, dan Bill Gates. Dari tokoh seniman muncul nama Vincent Van Gogh, Affandi Kusuma, Basuki Abdullah, dan Pramudya Ananta Tur. Dari tokoh motivator muncul nama Mario Teguh dan Merry Riana. Dari tokoh olahragawan muncul nama Muhammad Ali, Valentino Rossi, dan Cristiano Ronaldo. Sedangkan dari tokoh kaum milenial muncul nama Ria Yunita (Ria Ricis), Jerome Polin Sijabat, dan Tirta Mandira Hudhi.

Pengalaman hidup dari tokoh-tokoh yang diteladani oleh peserta didik tersebut diceritakan kembali oleh peserta didik dalam berbagai variasi konten format video yang dikirim melalui platform Google Classroom. Berdasarkan isi video tersebut, peserta didik tidak hanya mengagumi para tokoh, melainkan juga berusaha mengambil pelajaran hidup untuk memotivasi dirinya sendiri. Penugasan tersebut merupakan pembelajaran mandiri bagi peserta didik yang berfungsi untuk mengembangkan kompetensi diri seperti inisiatif, kepercayaan diri, manajemen waktu, dan peningkatan diri. Peserta didik didorong untuk melakukan kegiatan yang direncanakan di bawah pengawasan guru. Sementara itu, guru bertanggung jawab terhadap pengorganisasian kelas yang bersifat daring. Misalnya, merencanakan proses pengumpulan dan umpan balik, pemantauan kinerja, dan penyediaan sumber daya yang sesuai untuk kebutuhan belajar peserta didik.

\section{Fleksibilitas Pengorganisasian Kelas}

Pembelajaran yang bersifat daring menimbulkan tantangan dalam pengorganisasian kelas yang fleksibel. Oleh sebab itu, guru mengklasifikasi pengorganisasian kelas sesuai dengan interaksi guru dan peserta didik selama proses pembelajaran daring berlangsung. Pengorganisasian ini didukung dengan pemanfaatan teknologi yang canggih seperti Google Classroom, Hangouts Meet, dan Google Formulir.

Google Classroom merupakan situs platform pintar yang dikembangkan oleh perusahaan Google dengan tujuan untuk meningkatkan secara komprehensif pengalaman pembelajaran di kelas, meningkatkan interaksi guru dan peserta didik, dan membuat pembelajaran daring lebih fleksibel. Google Classroom mengembangkan menu yang sederhana ke dalam sistemnya seperti menu "forum" untuk diskusi antara siswa dan guru, menu "tugas kelas" (assignments) untuk pembuatan latihan, materi, dan kuis yang bisa ditautkan dengan berbagai situs sumber pembelajaran, menu "anggota" untuk mengatur jumlah anggota, dan menu "nilai" (grading) yang berfungsi sebagai asesmen pembelajaran.

Dengan bantuan Google Classroom, guru dapat mempublikasikan penugasan, latihan, dan materi, baik yang memiliki format buku elektronik, audio, animasi, dan video ke ponsel peserta didik, sehingga para guru dapat dengan mudah mendiagnosis masalah memberikan umpan balik.

Aplikasi hangouts meet dapat menutupi kekurangan google classrom yang tidak menyediakan fitur video siaran langsung. Aplikasi ini menyediakan siaran langsung kelas. Melalui aplikasi ini, peserta didik dapat menjawab pertanyaan dengan waktu nyata (real-time) dan berinteraksi dengan guru melalui layar ponsel/komputer.

Terakhir, google formulir digunakan oleh guru sebagai alat asesmen pembelajaran untuk mengetahui kompetensi pengetahuan peserta didik dalam mencapai kompetensi dasar pembelajaran.

Ketiga strategi pembelajaran tersebut cocok untuk pembelajaran mandiri peserta didik yang 
berorientasi pada penugasan dan pemecahan masalah semua jenis pembelajaran interaktif. $\mathrm{Hal}$ ini menginspirasi siswa untuk menggunakan media belajar dengan cara melihat pratinjau, mengulas, atau mengeksplorasi topik-topik yang sudah ditentukan. Sementara guru bertindak sebagai fasilitator yang menyediakan akses dan pengorganisasian kelas secara berkelanjutan agar kebutuhan kelas dapat difasilitasi dengan sebaik mungkin. Namun demikian, ketiga strategi pembelajaran tetap memiliki risiko potensial seperti terlihat pada Tabel 2.

Ruang kelas daring dengan pengorganisasian strategi pembelajaran tersebut lebih mudah dan lebih fleksibel daripada ruang kelas konvensional. Setelah guru masuk ke sistem aplikasi/situs, guru dapat mengevaluasi pembelajaran di kelasnya. Meskipun kelas terdiri atas banyak peserta didik, guru dapat dengan cepat mengetahui jawaban setiap peserta didik melalui pedoman instrumen daring (dashboard) yang dihasilkan oleh sistem.
Setelah peserta didik menyelesaikan latihan atau kuis, sistem secara otomatis menampilkan jawaban-jawaban yang sesuai dengan kemampuan mereka. Setiap kegiatan pembelajaran selesai, peserta didik akan segera mendapatkan umpan balik pada setiap pertanyaan dan proses penyelesaiannya. Ketika kelas sudah selesai, sistem akan secara otomatis menghasilkan laporan pembelajaran setiap masing-masing peserta didik, dan ini membantu guru memantau pembelajaran peserta didik dengan lebih baik. Hal itu sebagaimana yang terdapat pada Gambar 2.

Google Classroom dan Google formulir sebagai teknologi asesmen pembelajaran membantu guru untuk menilai keterampilan siswa dengan mudah dan cepat. Serta menemukan solusi untuk mengatasi kesenjangan pengetahuan antarpeserta didik, kemudian dapat menyesuaikan pembelajaran mereka dengan kebutuhan pembelajaran dalam konteks seharihari.

Tabel 2 Pengorganisasian Pembelajaran Daring di Kelas X SMK Negeri 5 Yogyakarta

\begin{tabular}{|c|c|c|c|}
\hline $\begin{array}{l}\text { Strategi } \\
\text { Pembelajaran }\end{array}$ & Sarana Teknis & $\begin{array}{l}\text { Pemanfaatan } \\
\text { Tekonologi }\end{array}$ & Risiko Potensial \\
\hline $\begin{array}{l}\text { Pembelajaran } \\
\text { daring dengan } \\
\text { panduan guru }\end{array}$ & $\begin{array}{l}\text { Ruang pembelajaran } \\
\text { daring dan media } \\
\text { evaluasi } \\
\text { pembelajaran } \\
\text { menggunakan situs } \\
\text { google classroom }\end{array}$ & $\begin{array}{l}\text { Situs website, } \\
\text { basis data, dan } \\
\text { media } \\
\text { pembelajaran }\end{array}$ & $\begin{array}{l}\text { Memungkinkan peserta did } \\
\text { tidak berpartisipasi aktif } \\
\text { mengikuti setiap proses } \\
\text { pembelajaran akibat bebar } \\
\text { tugas serta metode } \\
\text { pembelajaran guru yang } \\
\text { cenderung monoton }\end{array}$ \\
\hline $\begin{array}{l}\text { Pembelajaran } \\
\text { daring melalui } \\
\text { siarang langsung }\end{array}$ & $\begin{array}{l}\text { Platform siaran } \\
\text { langsung } \\
\text { menggunakan } \\
\text { aplikasi hangouts } \\
\text { meet }\end{array}$ & $\begin{array}{l}\text { Pembelajaran } \\
\text { tatap muka }\end{array}$ & $\begin{array}{l}\text { Memungkinkan peserta } \\
\text { tidak mengikuti siaran lar } \\
\text { akibat permasalahan teknis }\end{array}$ \\
\hline $\begin{array}{l}\text { Pembelajaran } \\
\text { daring dengan } \\
\text { komputasi waktu } \\
\text { nyata (real-time) }\end{array}$ & $\begin{array}{l}\text { Menggunakan situs } \\
\text { google formulir } \\
\text { sebagai asesmen } \\
\text { pembelajaran }\end{array}$ & $\begin{array}{l}\text { Situs website } \\
\text { dengan batas } \\
\text { waktu akses } \\
\text { untuk } \\
\text { mengerjakan kuis }\end{array}$ & $\begin{array}{l}\text { Memungkinkan peserta did } \\
\text { tidak mengikuti pembelajal } \\
\text { daring akibat abai terhada } \\
\text { informasi waktu pembelaja } \\
\text { yang bersifat real time }\end{array}$ \\
\hline
\end{tabular}




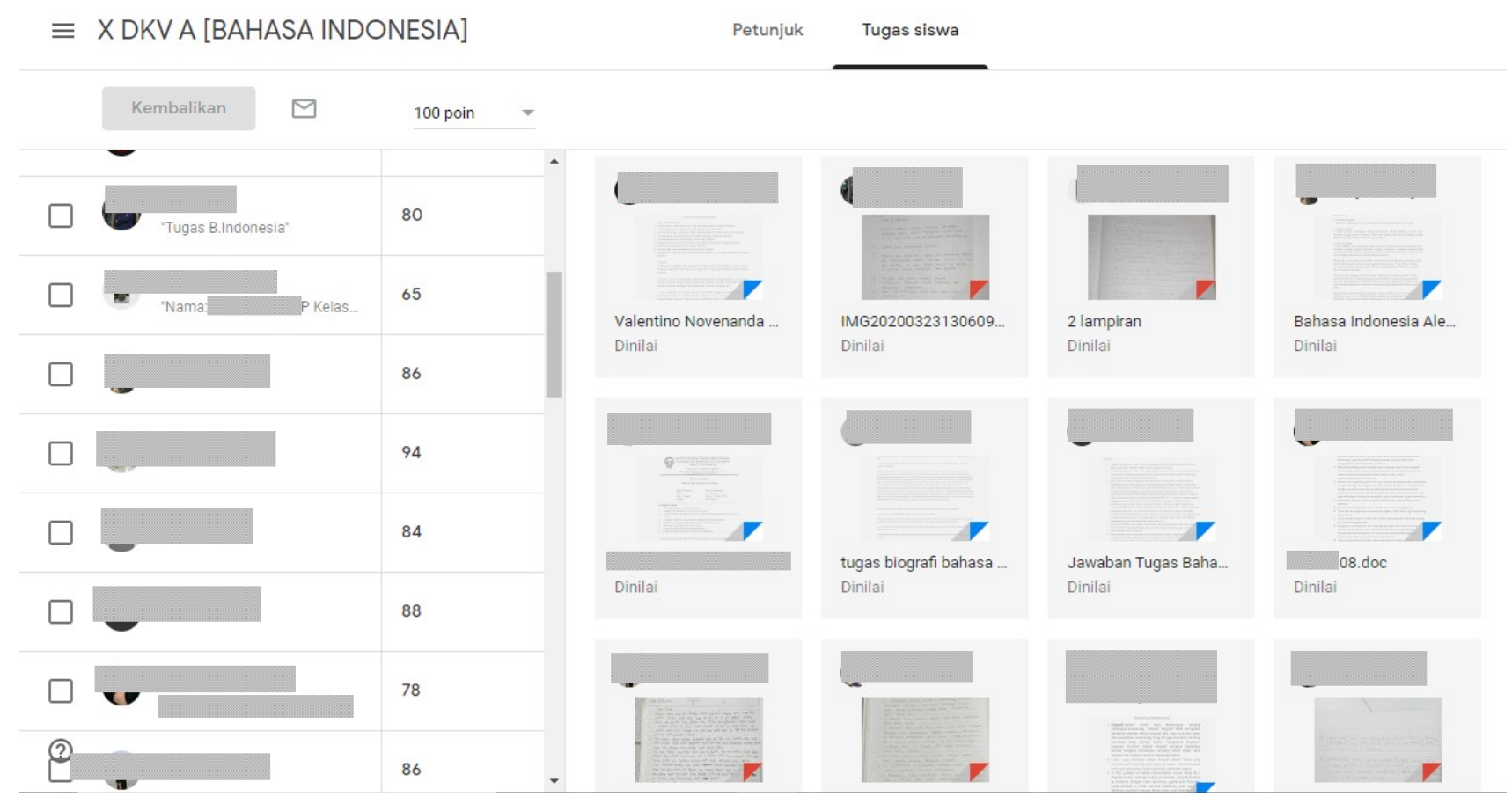

Gambar 2 Pemantauan Proses Pembelajaran Siswa melalui LMS Google Classroom

(Sumber: Windayani, 2020)

Selain itu, asesmen pembelajaran berbasis teknologi daring memberikan peningkatan fleksibilitas. Peserta didik dapat mengakses penilaian dengan cepat pada waktu yang paling sesuai dengan gaya dan kebutuhan belajar individu mereka. Mereka hanya membutuhkan perangkat internet dan lingkungan berbasis web atau virtual. Dengan pembelajaran yang dipersonalisasi pada teknologi terbukti memotivasi siswa untuk menjadi subjek mandiri dalam pembelajaran mereka sendiri (lihat Gambar 2).

Dengan demikian, asesmen pembelajaran saat masa pandemi harus menggabungkan pemeriksaan teknologi secara eksplisit dalam mendukung, memperluas, dan mentransformasikan pembelajaran peserta didik. Sistem teknologi penilaian baru diperlukan untuk menentukan strategi, prosedur, dan pengetahuan yang akan diuji saat peserta didik menggunakan teknologi untuk memecahkan masalah yang kompleks dalam domain materi pembelajaran. Asesmen pembelajaran berbasis teknologi fleksibel bertujuan untuk mendorong koherensi pembelajaran inovatif untuk mengembangkan kompetensi peserta didik di masa darurat Covid-19.

\section{SIMPULAN DAN SARAN}

\section{Simpulan}

Pembelajaran fleksibel di SMK Negeri 5 Yogyakarta memberikan kesempatan kepada peserta didik untuk menyajikan konten dengan cara baru dan inovatif dalam menggunakan kombinasi media dan mode pengiriman. Media sosial seperti instagram, twitter, facebook, tiktok, dan youtube dimanfaatkan oleh peserta didik sebagai basis konten untuk membagikan pekerjaan mereka dengan audien daring. Dengan demikian, proses pembelajaran daring teks biografi di kelas $X$ tidak hanya difungsikan untuk mencapai kompetensi dasar pembelajaran, melainkan juga berfungsi untuk mengampanyekan perlawanan terhadap pandemi Covid19.

Pengorganisasian pembelajaran daring di kelas X SMK Negeri 5 Yogyakarta mengoptimalkan penggunaan strategi pembelajaran 
fleksibel melalui media platform Google Classroom, Google Formulir, dan Hangouts Meet. Pengorganisasian kelas pembelajaran ini mampu mengakomodasi berbagai gaya belajar peserta didik yang berbeda-beda. Dengan demikian, fleksibilitas pengorganisasian kelas selama pembelajaran daring ditentukan dari keberhasilan guru dalam memilih strategi pembelajaran yang mandiri sehingga peserta didik mampu memiliki kebebasan untuk menentukan cara pembelajarannya sendiri. Guru mengoptimalkan perannya sebagai fasilitator peserta didik dengan cara memantau pembelajaran dari jarak jauh yang terintegrasi melalui sistem teknologi LMS yang canggih.

\section{Saran}

Pembelajaran teks biografi daring di kelas X SMK Negeri 5 Yogyakarta cenderung diprivatisasi ke arah pembelajaran individu. Akibatnya, proses pembelajaran cenderung abai terhadap pembelajaran kolaboratif, sehingga ke depannya pendekatan pembelajaran harus lebih bervariasi lagi untuk meningkatkan kerja sama antara peserta didik.

Guru perlu mengembangkan strategi pembelajaran yang lebih terjangkau paket data untuk memfasilitasi proses pembelajaran selama daring sehingga proses pembelajaran bisa diakses dengan mudah oleh berbagai latar belakang ekonomi peserta didik. Dengan demikian, proses pembelajaran selama masa pandemi juga memerlukan kerja sama antara berbagai pihak baik dari pemerintah, sekolah, korporasi, dan masyarakat untuk meningkatkan sumber daya pembelajaran.

\section{PUSTAKA ACUAN}

Anwas, O.M. (2011). Membangun media massa publik dalam menanamkan pendidikan karakter. Jurnal Pendidikan dan Kebudayaan, 17(6), 680-690 https://doi.org/10.24832/ jpnk.v17i6.59.

Anwas, O. M. (2014). Peran teknologi informasi dan komunikasi dalam implementasi Kurikulum 2013. Jurnal Teknodik, 17(1), 493-504. DOI: http://dx.doi.org/10.32550/teknodik.v0i0.62

Bušelić, M. (2012). Distance learning-concepts and contributions. Oeconomica Jadertina, 1(2), 23-34. https://doi.org/10.15291/oec.209.

Collis, B., Vingerhoets, J., \& Moonen, J. (1997). Flexibility as a key construct in European training: experiences from the telescopia project. British Journal of Educational Technology, 28(3), 199-217. https://doi.org/10.1111/1467-8535.00026.

Dewi, L. (2017). Rancangan program pembelajaran daring di perguruan tinggi: studi kasus pada mata kuliah kurikulum pembelajaran di Universitas Pendidikan Indonesia. Edutech, 16(2), 205-221. https://doi.org/10.17509/e.v16i2.7616\%0A.

$\mathrm{Er}, \mathrm{H}$. (2005). Biography teaching in social studies lesson; The analysis of (Atatük's life) articles and a new design. Gazi University.

Fertig, G. (2005). Teaching elementary students how to interpret the past. The Social Studies, 96(1), 2-8. https://doi.org/10.3200/tsss.96.1.2-8.

Giles, C., \& Hargreaves, A. (2006). The sustainability of innovative schools as learning organisations and professional learning communitites during standardised refrom. Educational Administration Quarterly, 42(1), 124-156. https://doi.org/https://doi.org/ $10.1177 \% 2 F 0013161 \times 05278189$. 
Goode, S., Willis, R.A., Wolf, J.R., \& Harris, A. L. (2007). Enhancing is education with flexible teaching and learning. Journal of Information Systems Education, 18(3), 297-302. researchgate.net/publication/

234630504_Enhancing_IS_Education_with_Flexible_Teaching_and_Learning.

Gordon, N. A. (2014). Flexible pedagogies: technology-enhanced learning. The Higher Education Academy, Januari 20. https://doi.org/10.13140/2.1.2052.5760.

Hannafin, M. J. (1984). Guidelines for using locus of instructional control in the design of computer-assisted instruction. Journal of Instructional Development, 3, 6-10. https:// doi.org/10.1007/BF02905753.

Huang, R.H., Liu, D.J., Tlili, A., Yang, J.F., \& Wang, H.H. (2020). Handbook on facilitating flexible learning during educational disruption: The Chinese experience in maintaining undisrupted learning in COVID-19 Outbreak. Smart Learning Institute of Beijing Normal University UNESCO.

Indaryanti, Susanti, E., Aisyah, N., \& Scristia. (2019). Analisis kesesuaian indikator terhadap kompetensi dasar pada pelajaran matematika oleh guru sekolah menengah Palembang. Jurnal Gantang, 4(2), 103-109. https://doi.org/10.31629/jg.v4i2.1429.

Joan, R. (2013). Flexible learning as new learning design in classroom process to promote quality education. I-Manager's Journal on School Educational Technology, 9(1), 37-42. https:// eric.ed.gov/?id=EJ1098325.

Kaymakcý, S., \& Er, H. (2009). The use of biography in social studies teaching. In M. Safran (Ed.), Social Studies Teaching. Pegema Academy.

Li, Q., Guan, X., Wu, P., Xiaoye, W., Zhou, L., Tong, Y., Ren, R., Kathy, Leung, Eric H.Y., Wong, J., Xing, X., \& Xiang, N. (2020). Early transmission dynamics in Wuhan, China, of novel coronavirus-infected pneumonia. The New England Journal of Medicine, https:// www.nejm.org/doi/full/10.1056/NEJMoa2001316.

Mahase, E. (2020). China coronavirus: WHO declares international emergency as death toll exceeds 200. BMJ (Clinical Research Ed.). https://doi.org/10.1136/bmj.m408.

Meng, L., Hua, F., \& Bian, Z. (2020). Coronavirus Disease 2019 (COVID-19):Emerging and Future Challenges for Dental and Oral Medicine. Journal of Dental Research, 99(5), 481-487. https://doi.org/10.1177/0022034520914246.

Keputusan Menteri Kesehatan tentang Penetapan Infeksi Novel Coronavirus (Infeksi 2019-nCoV) sebagai Penyakit yang Dapat Menimbulkan Wabah dan Upaya Penanggulangannya, Pub. L. No. Hk.01.07/Menkes/104/2020 (2020).

Kementerian Kesehatan Republik Indonesia. (2020). Situasi Covid-19. https:// www.kemkes.go.id/, diakses 26 April 2020.

Kementerian Pendidikan dan Kebudayaan Republik Indonesia tentang Pelaksanaan Kebijakan Pendidikan dalam Masa Darurat Penyebaran Coronavirus Disease (COVID-19), Pub. L. No. Nomor 4 Tahun 2020 (2020).

Miles, M.B., Huberman, M., \& Saldana, J. (2014). Qualitative data analysis: A methods sourcebook. Sage Publications. 
Phelan, A.L., Katz, R., \& Gostin, L.O. (2020). The Novel Coronavirus Originating in Wuhan, China: Challenges for Global Health Governance. In JAMA - Journal of the American Medical Association. https://doi.org/10.1001/jama.2020.1097.

Peraturan Pemerintah Republik Indonesia tentang Pembatasan Sosial Berskala Besar dalam Rangka Percepatan Penanganan Corona Virus Disease 2019(COVID-19), Pub. L. No. Nomor 21 Tahun 2020 (2020).

Purwanto, A., Pramono, R., Asbari, M., Santoso, P.B., Wijayanti, L. M., Hyun, C.C., \& Putri, R. S. (2020). Studi eksploratif dampak pandemi COVID-19 terhadap proses pembelajaran online di sekolah dasar. Journal of Education, Psychology, and Counseling, 2(1), 1-12. https:// ummaspul.e-journal.id/Edupsycouns/article/view/397.

Ryan, A., \& Tilbury, D. (2013). Flexible pedagogies: new pedagogical ideas. flexible pedagogies: preparing for the future series. In Higher Education Academy. https://s3.eu-west2.amazonaws.com/assets.creode.advancehe-document-manager/documents/hea/ private/resources/npi_report_1568036616.pdf.

Smyth, J., \& McInerney, P. (2013). Making "space": young people put at a disadvantage reengaging with learning. British Journal of Sociology of Education, 34(1), 39-55. https:// doi.org/10.1080/01425692.2012.744735.

Steinberg, E.R. (1989). Cognition and learner control: a literature review, 1977-1988. Journal of Computer-Based Instruction, 16(4), 117-121. https://dl.acm.org/doi/10.5555/ 70831.70832.

Susanti, E., Halimah, M., Harta, R., \& Karyana, A. (2018). Desain video pembelajaran yang efektif pada pembelajaran jarak jauh: studi di Universitas Terbuka. Jurnal Pendidikan Dan Kebudayaan, 3(2), 167-185. https://doi.org/10.24832/jpnk.v3i2.929.

te Riele, K. (2006). Youth 'at risk': further marginalizing the marginalized? Journal of Education Policy, 21(2), 129-145. https://doi.org/10.1080/02680930500499968.

te Riele, K. (2012). One size does not fit all-belonging and marginalised youth. In Bagnall \& E. Cassity (Eds.), Education and belonging. Nova Science.

Windayani, D. (2020). Fleksibilitas pembelajaran daring di SMK Negeri 5 Yogyakarta. Hasil Dokumentasi Pribadi: 13 April 2020.

World Health Organization. (2020). Coronavirus disease 2019 (COVID-19): situation report-36. World Health Organization. https://www.who.int/docs/default-source/coronaviruse/ situation-reports/20200225-sitrep-36-covid-19.pdf?sfvrsn=2791b4e0_2., diakses 26 April 2020. 